\title{
Composition Analysis of Essential Oil from Eleven Species of Cupressaceae in East China
}

\author{
Lin Lejing, Fu Tao, Zhang Lijun \\ Ningbo City College of Vocational Technology, Ningbo 315502
}

Keywords: Cupressaceae, Essential Oil, GC-MS

\begin{abstract}
The essential oil obtained from the leaves of Cupressaceae were analyzed in this study. The volatile oil was obtained by ethyl acetate distillation and then analyzed by gas chromatography-mass spectrum(GC-MS). The study showed that Sabina procumbens (Endl.) Iwata et Kusaka, Sabina virginiana (L.) Antoine, Sabina squamata (Buch.-Hamilt.) Ant and Sabina chinensis(L.) Antoine cv. Pfitzeriana (Sabina), Fokienia hodginsii (Dunn) Henry et Thomas (Fokienia hodginsii) and Chamaecyparis obtuse cv. Tetragon (Chamaecyparis) were mainly composed of terpene and alcohols. American arborvitae, Thuja standishii (Gord.) Carr, Thuja occidentalis L. (valuable arborvitae), Cupressus arizonica Greene (cypresses) and Platycladus orientalis 'sieboldii' (Platycladus) were mainly composed of terpene, alcohols and ketones. There were 49 kinds of common components $(\geq 6)$ in 11 kinds of plants, accounting for only $10.71 \%$ of all essential oil components, and more specific components $(\leq 5)$, common composition and unique elements together make each plant smell differently.
\end{abstract}

\section{Introduction}

It is found that the main chemical constituents of cypress include volatile oil (terpenes), flavonoids, phenols, organic acids, polysaccharides, lignans, tannins, resins and inorganic elements [1]. Among them, volatile oil is the most important secondary metabolite of cypress. Its content is high and its composition is the most complex [2-3]. It has many pharmacological functions such as bacteriostasis, anti-tumor and anti-oxidation.

\section{Materials and Methods}

\subsection{Main instruments and devices}

HP7890B GC system/5977A MSD gas chromatography-mass spectrometry: America Agilent Technologies company with Agilent chromatographic column Agilent 19091S-433:93.92873 HP-5MS 5\% Phenyl Methyl silox $-60^{\circ} \mathrm{C}-325^{\circ} \mathrm{C}\left(325^{\circ} \mathrm{C}\right): 30 \mathrm{~m} \times 250 \mu \mathrm{m} \times 0.25 \mu \mathrm{m}$; METTLER TOLEDO electronic balance: METTLER TOLEDO company; MLLI-Q- ultrapure water meter: American Millipore company; Volatile oil extractor: North Beijing Ruida Medical Technology Company; 0.45 $\mu$ m filter: APEL Laboratory Technologies (Shanghai) Inc [4-5].

\subsection{Major materials and reagents}

Platycladus orientalis' sieboldii 'and Thuja standishii Carr were collected at the Shanghai Chen Shan Botanical Garden in November 14, 2015; Sabina procumbens in November 28, 2015 were collected in the Hangzhou Botanical Garden (Endl.) Iwata Kusaka, Sabina virginiana Antoine (L.), Sabina Squamata (Buch.-Hamilt.), Ant Sabina chinensis (L.) Antoine cv. Pfitzeriana, American arborvitae, Fokienia hodginsii (Dunn) Henry et Thomas, Cupressus arizonica Greene, Thuja occidentalis and L. Chamaecyparis obtuse cv. Tetragon.

\subsection{Test conditions}

\subsubsection{Extraction of volatile oil from 11 Cupressaceae plants of the family cypress}

The method of extracting the reference stand of the volatile oil is slightly improved. Respectively 
from 11 Cupressaceae plants healthy leaves of $100 \sim 150 \mathrm{~g}$, using scissors to cut into pieces and placed in a flask shaped; adding pure water $850 \mathrm{~mL}$ and pure grade ethyl acetate $5 \mathrm{~mL}$, adding a certain amount of zeolite and fully shaking it; after $1 \mathrm{~h}, 3 \mathrm{~h}$ was extracted by atmospheric vapor distillation, and $0.5 \mathrm{~h}$ was cooled by cooling. The water layer, the receiving oil layer, and the water removal of the anhydrous sodium sulfate were used for 2 times; Finally, using filter $0.45 \mathrm{~m}$ oil like mixture for subsequent sampling and analysis.

\subsubsection{GC condition}

The column temperature of $40^{\circ} \mathrm{C}$; the inlet temperature of $250{ }^{\circ} \mathrm{C}$; the column carrier gas flow rate is $1.0 \mathrm{~mL} / \mathrm{min}$; carrier gas of high purity helium $(99.999 \%)$; the temperature of vaporizing chamber $250{ }^{\circ} \mathrm{C}$, column pressure 7. $62 \mathrm{kPa}$; temperature program: to keep $1 \mathrm{~min}$ from $40{ }^{\circ} \mathrm{C}$; at the temperature of $40^{\circ} \mathrm{C}$ to $140{ }^{\circ} \mathrm{C}, 2$ min was maintained and then $2^{\circ} \mathrm{C} / \mathrm{min}$ was raised to $225^{\circ} \mathrm{C}$ and 5 min was maintained; injection volume was $1 \mu \mathrm{L}$ and split ratio was 5:1.

\subsubsection{MS condition}

The EI ion source; the ion source temperature is $230{ }^{\circ} \mathrm{C}$; the interface temperature is $250{ }^{\circ} \mathrm{C}$; the electron energy is $70 \mathrm{eV}$; the MS four rod temperature is $150{ }^{\circ} \mathrm{C}$; the tuning EMV is 1149 ; the solvent time is $2.6 \mathrm{~min}$; the scanning range is $15 \sim 500 \mathrm{Amu}$.

\subsection{Data processing}

The Nist 05 standard mass spectrogram library and wiley 275 mass spectrogram library was retrieved by HP Chemstation. Meanwhile; the relevant mass spectrogram analysis was used to confirm the volatile components of tomorrow's leaves [6-8]. Through the HP chemstation data processing system, the relative percent of the chemical components are calculated by the method of peak area normalization.

SPSS19.0 software (IBM SPSS Statistics) was used to analyze the results of GC-MS analysis by clustering (CA).

\section{Results and Analysis}

\subsection{Classification of volatile oil components from leaves of 11 species of Cupressaceae plants}

The number of volatile oil compounds from 11 species of Cupressaceae leaves was 106, 127, 63, $114,111,105,103,50,142,77$ and 142 respectively. The essential oils of the 11 cypress plants can be roughly classified into 7 categories: terpenes, alcohols, ketones, esters, organic acids, hydrocarbons and their derivatives, etc., and each species of cypress plants and their species contents are in Table 1. Table 1 shows the characteristics of Sabina procumbens (Endl.) Iwata et Kusaka, Sabina virginiana, Sabina squamata (Buch.Ham.) Ant. and Sabina chinensis cv. Pfitzeriana (Sabina Mill.) are volatile terpenes and alcohols (the total content and were 81.93\%, 81.39\%, 77.34\% and 81.79\%), other components were less; American arborvitae, Thuja standishii Linn. and Thuja occidentalis L. (Thuja) are volatile terpenes, alcohols and ketones (the total content and were 83.23\%, 82.77\% and 87.56\%), of which 3 kinds of ketones in the Thuja was relatively high; Fokienia hodginsii (Dunn) Henry et Thomas (Fokienia Henry et Thomas) and Chamaecyparis obtusa (Sieb. et Zucc.) Endl. (Chamaecyparis Spach) are similar to Sabina Mill., which are all terpenes and alcohols (the total content and were $79.11 \%$ and $76.33 \%$ ); the contents of esters in Chamaecyparis obtusa (Sieb. et Zucc.) Endl. are also high, which is 21\%; Cupressus arizonica Greene (Cupressus Linn) and Platycladus orientalis (L.) Franco 'Sieboldii' (Platycladus Spach) are similar to Thuja, which all have terpene, alcohols and ketones (the sum of total content was $83.24 \%$ and $90.24 \%$ in turn).

\subsection{Analysis of the components of volatile oil from the leaves of 11 species of Cupressaceae plants}

From Table 2, we can see that although 11 kinds of Cupressaceae plants have the same type (belonging to the same genus) and the difference (different genera) but the specific components are quite different (even the same plants). The common components (more than 6) there are 39 kinds of 
material, all the material accounted for only $8.53 \%$.

From Table 2, we also know that terpenes account for 20 kinds in the total components, alcohols account for 11, ketones are 3 and esters are 2 . It shows that the volatile oil of cypress plants are mainly enoles and also contain a few ketones and esters. The details are detailed in Table 2.

\section{Conclusion and Discussion}

The volatile oil was extracted from 11 Cupressaceae plants by steam distillation method, because of the high temperature, resulting in some terpenes (or other easily oxidized substances) is easily oxidized, so the study found that the oxidation of organic compounds containing a certain amount of species composition in part (which is divided from other of course), have a certain impact on the content of the test results of other components of species. The results from previous studies are consistent with terpenes and alcohols (some of which also contain ketones or esters).

11 Cupressaceae plants are common components in many materials have many biological effects, such as the limonene has expectorant and antitussive effect; caryophyllene has antiasthmatic effect, obvious therapeutic effect on senile chronic bronchitis; in addition, which also contains some antimicrobial ingredients such as bornyl acetate, the obvious sterilizing effect. The 11 Cupressaceae plants have medicinal value, the volatile oil can develop biological fungicides, insecticides or added to the liquid detergent, soap and other common household items can also be used for medium, parks, schools, and other special places for medical abdominal "forest therapy", with better effects in medical care.

Most Cupressaceae plants have strong aroma, which is related to a lot of low boiling point and low molecular weight substances such as terpenes and alcohols, such as terpenes and alcohols. In Table 2, most of the components in the Communist Party are low boiling point and low molecular weight substances such as terpenes and alcohols. The aromatic odor of cypress plants is closely related to these volatile substances. Yang and other studies on propolis showed that the sense of smell in human body is related to its odor and its content and odor threshold. Low content may be easily perceived due to low odor threshold. Conversely, compounds with high content may be difficult to perceive due to high odor threshold.

In this study, GC-MS was used to simultaneously and accurately determine the relative content of the Cupressaceae Plants. It mainly contains 4 species of Sabina Mill. (Sabina procumbens (Endl.) Iwata et Kusaka, Sabina virginiana, Sabina squamata (Buch.Ham.) Ant., and Sabina chinensis cv. Pfitzeriana), Fokienia hodginsii (Dunn) Henry et Thomas (Fokienia Henry et Thomas) and Chamaecyparis obtusa (Sieb. et Zucc.) Endl. mainly including terpenes and alcohols; 3 species of Thuja (American arborvitae, Thuja standishii Linn. and Thuja occidentalis L.), Cupressus arizonica Greene (Cupressus Linn) and Platycladus orientalis (L.) Franco 'Sieboldii'(Platycladus Spach) mainly including terpenes, alcohols and ketones. There are 39 species of 11 kinds of Cupressaceae Plants common components (more than 6) accounted for only 8.53\% of all material. The special odor of each species of plants may be manifested by the combination and superposition of these common components and endemic components. The results of this study provide a certain theoretical basis for the rational utilization of the plants of the family cypress.

\section{References}

[1] Ibrahim T A, Elhela A A, Elhefnawy H, et al. Chemical Composition and Antimicrobial Activities of Essential Oils of Some Coniferous Plants Cultivated in Egypt[J]. Iranian Journal of Pharmaceutical Research Ijpr, 2017, 16(1):328-337.

[2] Mustafa B, Nebija D, Hajdari A. Chemical composition of the essential oils of Juniperus communis subsp. alpina (Suter) Čelak (Cupressaceae)[C]// Macedonian pharmaceutical bulletin. 2016.

[3] Li R, Hu H B, Li X F, et al. Essential oils composition and bioactivities of two species leaves used as packaging materials in Xishuangbanna, China[J]. Food Control, 2015, 51(3):9-14. 
[4] Zhang L, Yang Z, Wei J, et al. Contrastive analysis of chemical composition of essential oil from twelve Curcuma species distributed in China[J]. Industrial Crops \& Products, 2017, 108:17-25.

[5] Zeljković S Ć, Maksimović M. Chemical composition and bioactivity of essential oil from Thymus, species in Balkan Peninsula [J]. Phytochemistry Reviews, 2015, 14(3):335-352.

[6] Koutsaviti K, Giatropoulos A, Pitarokili D, et al. Greek Pinus, essential oils: larvicidal activity and repellency against Aedes albopictus, (Diptera: Culicidae) [J]. Parasitology Research, 2015, 114(2):583-592.

[7] Yang K, You C X, Wang C F, et al. Chemical Composition and Bioactivity of Essential Oil of Atalantia guillauminii against Three Species Stored Product Insects[J]. Journal of Oleo Science, 2015, 64(10):1101.

[8] Trombinsouza M, Trombinsouza M, Amaral W, et al. Chemical composition of the essential oils of Baccharis species from southern Brazil: a comparative study using multivariate statistical analysis [J]. Journal of Essential Oil Research, 2017:1-7. 
Table 1 . The species and relative content of the volatile oil of 11 species of cypress plants

\begin{tabular}{|c|c|c|c|c|c|c|c|c|c|c|c|}
\hline \multirow[b]{2}{*}{ Species of volatile oil } & \multicolumn{11}{|c|}{ Content \% } \\
\hline & $\begin{array}{l}\text { Sabina procumbens } \\
\text { (Endl.) Iwata et } \\
\text { Kusaka }\end{array}$ & $\begin{array}{c}\text { Sabina } \\
\text { virginiana }\end{array}$ & $\begin{array}{l}\text { Sabina squamata } \\
\text { (Buch.Ham.) } \\
\text { Ant. }\end{array}$ & $\begin{array}{c}\text { Sabina } \\
\text { chinensis cv. } \\
\text { Pfitzeriana }\end{array}$ & $\begin{array}{l}\text { American } \\
\text { arborvitae }\end{array}$ & $\begin{array}{c}\text { Thuja } \\
\text { standishii Linn. }\end{array}$ & $\begin{array}{c}\text { Thuja } \\
\text { occidentalis L. }\end{array}$ & $\begin{array}{c}\text { Fokienia } \\
\text { hodginsii (Dunn) } \\
\text { Henry et Thomas }\end{array}$ & $\begin{array}{l}\text { Cupressus arizonica } \\
\text { Greene }\end{array}$ & $\begin{array}{l}\text { Chamaecyparis } \\
\text { obtusa (Sieb. et } \\
\text { Zucc.) Endl. }\end{array}$ & $\begin{array}{c}\text { Platycladus } \\
\text { orientalis (L.) } \\
\text { Franco } \\
\text { 'Sieboldii' } \\
\end{array}$ \\
\hline Terpenes & $48.04(38)$ & 43.79 (39) & $51.40(28)$ & $45.95(38)$ & $51.21(26)$ & $43.84(29)$ & $44.94(27)$ & 45.89 (17) & $48.41(43)$ & $55.19(31)$ & $30.8(20)$ \\
\hline Alcohols & 33.89 (29) & $37.60(47)$ & $25.94(15)$ & $35.84(35)$ & $17.06(37)$ & $20.93(34)$ & $24.57(27)$ & 33.22 (15) & $20.88(40)$ & $21.14(23)$ & $30.37(38)$ \\
\hline Ketone & $5.54(11)$ & $8.59(11)$ & $8.25(10)$ & $4.27(11)$ & $14.96(18)$ & 18.00 & 18.05 (19) & $6.37(3)$ & 13.95 (19) & $2.03(6)$ & $29.07(17)$ \\
\hline Esters & $10.43(13)$ & $2.87(9)$ & $5.56(3)$ & $10.34(8)$ & $13.75(9)$ & $13.17(12)$ & $12.29(9)$ & $4.74(3)$ & $8.39(11)$ & $21.00 （ 6 ）$ & $1.22(5)$ \\
\hline Organic acid & $0.37(2)$ & $0.02(1)$ & $0.22(1)$ & $0.84(4)$ & $0.01(1)$ & 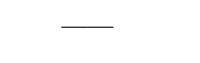 & $0.04(1)$ & $0.98(2)$ & 0.14 (3) & - & $0.26(2)$ \\
\hline $\begin{array}{l}\text { Hydrocarbons and } \\
\text { their derivatives }\end{array}$ & $0.98(5)$ & $0.45(8)$ & $1.09(1)$ & 0.33 (8) & $0.94(4)$ & $2.55(7)$ & $4.83(7)$ & $5.36(3)$ & $2.76(7)$ & $0.12(3)$ & $2.76(6)$ \\
\hline Others & $0.75(8)$ & $6.68(12)$ & $7.54(5)$ & $2.43(10)$ & $2.07(16)$ & $1.51(11)$ & $5.28(13)$ & $3.44(7)$ & $5.47(19)$ & $0.52(8)$ & $5.52(7)$ \\
\hline
\end{tabular}

Note: the number of parentheses in the table is the number of specific components

Table 2. 11 Cupressaceae plants total volatile oil (over 6) and its relative content

\begin{tabular}{|c|c|c|c|c|c|c|c|c|c|c|c|}
\hline \multirow[b]{2}{*}{ Volatile oil components } & \multicolumn{11}{|c|}{ Content $/ \%$} \\
\hline & $\begin{array}{l}\text { Sabina procumbens } \\
\text { (Endl.) Iwata et } \\
\text { Kusaka }\end{array}$ & $\begin{array}{l}\text { Sabina } \\
\text { virginiana }\end{array}$ & $\begin{array}{l}\text { Sabina squamata } \\
\text { (Buch.Ham.) Ant. }\end{array}$ & $\begin{array}{l}\text { Sabina chinensis } \\
\text { cv. Pfitzeriana }\end{array}$ & $\begin{array}{l}\text { American } \\
\text { arborvitae }\end{array}$ & $\begin{array}{l}\text { Thuja standishii } \\
\text { Linn. }\end{array}$ & $\begin{array}{c}\text { Thuja occidentalis } \\
\text { L. }\end{array}$ & $\begin{array}{c}\text { Fokienia } h \\
\text { odginsii } \\
\text { (Dunn) Hen } \\
\text { ry et Thoma } \\
\text { s } \\
\end{array}$ & $\begin{array}{l}\text { Cupressus } \\
\text { arizonica } \\
\text { Greene }\end{array}$ & $\begin{array}{l}\text { Chamaecyparis } \\
\text { obtusa (Sieb. } \\
\text { et Zucc.) Endl. }\end{array}$ & $\begin{array}{l}\text { Platycladus } \\
\text { orientalis } \\
\text { (L.) Franco } \\
\text { 'Sieboldii' }\end{array}$ \\
\hline D-Limonene & 0.18 & 0.70 & 3.45 & 4.86 & 1.63 & 4. 00 & 3.22 & 3. 10 & 5.71 & 2. 95 & 0.50 \\
\hline$\beta$-Phellandrene & - & 0.47 & 4. 03 & 7.31 & 6.75 & 12. 15 & 6.80 & 5.32 & 7.36 & 1.39 & 1.61 \\
\hline$\beta$-Pinene & - & 0.09 & 0.89 & 3.41 & 1. 59 & 3. 66 & 3. 80 & 0.85 & 2. 80 & 0.92 & 0.02 \\
\hline a-Bulnesene & 0.96 & 0.27 & - & 0.13 & 0.09 & 0.14 & 0.22 & - & - & 0.01 & - \\
\hline (+)-4-Carene & - & 0.05 & 1. 20 & 0.03 & 1. 30 & 0.77 & 0.82 & 0.54 & 0.08 & - & 0.25 \\
\hline Caryophyllene & 4.98 & 0.31 & 0.06 & 0.13 & - & 1.95 & 0.20 & 2. 13 & 0.08 & 1. 47 & - \\
\hline Thu jone & - & 0.11 & 4. 89 & 0.24 & 23.82 & - & 0.02 & 4. 91 & 3.21 & 0.79 & 14.69 \\
\hline$\gamma$-Terpinene & - & - & 2. 29 & 3.94 & 2. 01 & 2.27 & 2. 16 & 0.97 & 3.86 & 1. 09 & 0.49 \\
\hline$\beta$-copaene & 0.33 & - & 0.02 & 0.02 & 0.03 & 0.07 & - & 0.25 & - & 1.14 & - \\
\hline a -Phellandrene & - & - & 0.56 & 0.08 & 0.58 & 4. 60 & - & 0.59 & 0.89 & 0.42 & 0.08 \\
\hline a-Pinene & - & - & 0.95 & 1.51 & 0.97 & - & 0.16 & 1. 42 & 2. 09 & 1. 24 & 0.20 \\
\hline Camphene & - & - & 1.85 & 0.68 & 1.33 & 0.89 & 0.74 & 0.16 & 2. 40 & 2. 00 & 0.30 \\
\hline Humulene & 3. 70 & 0.20 & 0.10 & 0.08 & 0.09 & 1. 20 & 0.06 & 0.34 & 0.04 & - & - \\
\hline 3-Carene & - & - & 2. 94 & 0.06 & - & 0.15 & 0.03 & 1.43 & 2. 14 & 2. 24 & 0.11 \\
\hline Bornyl acetate & - & 0.42 & 3.81 & 7. 10 & 6. 96 & 8.06 & 9.60 & 1.81 & 4. 11 & 1.81 & 0.48 \\
\hline$\gamma$-Muurolene & 27. 43 & 3. 12 & 0.04 & 0.59 & - & 2.13 & 1.93 & 8.16 & - & 0.89 & 0.86 \\
\hline
\end{tabular}




\begin{tabular}{|c|c|c|c|c|c|c|c|c|c|c|c|}
\hline$\gamma$-Elemene & 0.66 & - & - & 0.29 & - & 0.20 & 0.04 & 1.60 & - & - & 0.20 \\
\hline . alfa.-Copaene & 2. 54 & - & 0.18 & 2. 86 & - & 0.03 & 0.05 & 1.52 & 0.62 & 3. 22 & 1.36 \\
\hline a-Muurolene & 0.31 & - & - & 0.08 & 0.06 & 0.14 & 0.60 & 1.95 & - & 0.10 & 0.28 \\
\hline Cubenol & 4. 19 & 9. 46 & 0.17 & - & 0.09 & 1. 49 & 1.38 & 1.93 & 1.09 & 4. 31 & 4. 35 \\
\hline $\begin{array}{l}\text { (+)-epi-Bicyclosesquiphe } \\
\text { llandrene }\end{array}$ & - & 4. 55 & - & 8.91 & - & 2.79 & 0.80 & 0.54 & 0.42 & - & - \\
\hline Caryophyllene oxide & 1.60 & 0.15 & 2.83 & - & 0.35 & 0.37 & - & 1.56 & 2.29 & 0.59 & 3. 49 \\
\hline p-Menth-8-en-1-ol & - & - & 0.55 & 0.81 & 0.93 & 0.36 & - & 0.22 & - & 0.12 & 0.51 \\
\hline Cadinol & 9.28 & - & 0.11 & 0.69 & - & 1.26 & - & - & 0.16 & 1.95 & 1. 20 \\
\hline a-Cadinol & 1.76 & 2. 94 & 0.80 & 0.54 & - & 1.72 & - & 2. 22 & 0.16 & 2. 15 & 2.61 \\
\hline $\begin{array}{c}\text { Atis-16-ene, }(5 \beta, 8 a, 9 \\
\beta, 10 a, 12 a)-\end{array}$ & 1.65 & 0.29 & 0.06 & - & 0.20 & 0.09 & 0.02 & 0.25 & 5.00 & 0.05 & 5.70 \\
\hline endo-Borneol & - & - & 1.90 & 1. 56 & 1. 17 & 0.45 & 2.62 & 0.25 & 0.21 & - & 0.31 \\
\hline Terpinen-4-ol & - & - & 3.14 & 3.13 & 6.05 & 4.90 & 0.45 & 1.39 & 1.61 & 0.90 & 2.14 \\
\hline Trachylobane & 2. 54 & 1.08 & - & 0.04 & - & 0.37 & - & 0.59 & - & - & 0.18 \\
\hline Androsta-3, 5-dien-7-one & 0.49 & 2. 79 & 0.30 & - & - & 0.34 & - & 0.13 & 0.19 & - & 1.38 \\
\hline 4-epi-cubedol & - & 0.83 & - & 2. 52 & - & 1.61 & 1.75 & 2.86 & 0.92 & 5.17 & 4. 46 \\
\hline Kaur-16-ene, $(8 \beta, 13 \beta)-$ & 0.86 & 2. 63 & 0.10 & 0.40 & 0.18 & 1.46 & - & - & 0.08 & 4.08 & 0.42 \\
\hline cubedol & - & 0.47 & - & 1.25 & - & 1.30 & - & 0.59 & 1.21 & - & 5.04 \\
\hline Thymol & - & - & 0.74 & 0.02 & 0.02 & - & 0.09 & - & 0.26 & - & 0.45 \\
\hline a-Terpineol & - & - & 0.50 & 0.78 & 0.66 & 0.27 & - & 0.11 & 3.74 & 2.12 & 1.61 \\
\hline $\begin{array}{l}\text { Podocarp-7-en-3-one, } 13 \\
\beta \text {-methyl-13-vinyl- }\end{array}$ & 3. 02 & 1.76 & 0.07 & - & - & 1.12 & 1.12 & 1.05 & - & 0.34 & 0.15 \\
\hline 4, 14-Retro-retinol & 0.57 & 0.51 & - & - & 0.04 & 0.19 & 0.14 & 0.17 & - & - & 0.19 \\
\hline Isoshyobunone & - & 0.58 & 0.16 & 1.32 & 0.04 & - & - & 0.08 & - & 0.64 & 0.72 \\
\hline a-acorenol & - & 3. 82 & 0.53 & 0.02 & 0.10 & 0.15 & 0.02 & 1.63 & - & 0.34 & - \\
\hline Guaiol & - & 1.83 & - & 8.27 & - & 3. 54 & 24. 10 & 14.07 & - & - & 1. 10 \\
\hline $\begin{array}{l}\text { Podocarpa-6, 13-diene, } 13 \\
\text {-isopropyl- }\end{array}$ & - & 0.77 & - & 0.40 & - & 0.11 & 0.33 & 1.53 & - & 0.02 & - \\
\hline Ferruginol & - & 2. 13 & 0.98 & 0.16 & - & 1.32 & 0.70 & 0.07 & 0.06 & 0.19 & 2. 20 \\
\hline $\begin{array}{l}\text { 13-Isopropylpodocarpen-1 } \\
\text { 2-ol-20-al }\end{array}$ & - & 6.22 & - & 0.08 & - & - & 0.63 & 0.16 & 0.31 & 1. 10 & 1. 18 \\
\hline Prasterone & - & 0.14 & 0.04 & 0.02 & - & 0.26 & - & 0.02 & 0.03 & 0.13 & 0.13 \\
\hline Fenchyl acetate & - & - & 0.94 & 0.07 & 5.18 & 0.80 & - & 0.12 & 0.82 & 0.05 & - \\
\hline $\begin{array}{c}\text { cis-p-Mentha-2, 8-dien-1- } \\
\text { ol }\end{array}$ & - & - & 0.31 & 0.01 & 0.13 & 0.02 & 0.02 & - & 0.30 & 0.10 & 0.14 \\
\hline Kaur-16-ene & - & - & 12. 45 & 2. 59 & 0.49 & - & - & 1.08 & 10.09 & 0.64 & 0.65 \\
\hline $\begin{array}{l}\text { 17-Norkaur-15-ene, } 13 \text {-me } \\
\text { thyl-, }(8 \beta, 13 \beta)-\end{array}$ & - & - & 12.63 & 9.76 & 3. 20 & 0.04 & 0.04 & - & 11.12 & 0.59 & - \\
\hline (+)-2-Bornanone & - & - & - & 0.39 & 0.37 & 0.26 & 1.47 & 0.29 & - & - & 3.06 \\
\hline
\end{tabular}

